\title{
がん免疫療法の時代がやってきた
}

\author{
中面哲也
}

\section{Era of cancer immunotherapy has come}

Tetsuya NAKATSURA

Division of Cancer Immunotherapy, Exploratory Oncology Research \& Clinical Trial Center, National Cancer Center

(Accepted March 31, 2016)

summary

The dramatic and long durable anti-tumor effect of immune checkpoint blockade, such as anti-CTLA-4 Ab, anti-PD-1 $\mathrm{Ab}$, and anti-PD-L1 Ab was surprised the world. In addition, CAR-T cell therapy that target the CD19 indicates a very high response rate to the CD19-positive hematologic malignancies. Now, no one doubts the presence of immunity against cancer.

Further, accordingly, tumor-specific neoantigen are attention now, the clinical trials of individualized peptide vaccination that target patient individual neoantigens has begun in the Western. On the other hand, the peptide vaccine therapy that target common self-antigen is not yet been approved in Japan, the development is struggling.

In this paper, I overview the cancer immunotherapy and neoantigen and introduce some development of cancer immunotherapy in Japan.

Key words_— cancer immunotherapy; immune checkpoint blockade; neoantigen; chimeric antigen receptor (CAR); cancer vaccine

抄 録

抗 CTLA-4 抗体, 抗 PD-1 抗体, 抗 PD-L1 抗体などのいわゆる免疫チェックポイント阻害抗体の登場により, そ の劇的かつ長く効く抗腫瘍効果は世界を驚かせ，さらには，CD19を標的とした CAR-T 細胞療法は CD19 陽性造血 器腫瘍に対して極めて高い奏効率を示し，今や，がんに対する免疫の存在，それらの治療法の有効性について疑う 者はいなくなった，また，それに伴い，腫瘍特異的変異抗原（ネオアンチゲン）が注目されて㧍り，今や，患者個 別のネオアンチゲンを同定してのそれらを標的とした個別化ペプチドワクチン療法の臨床試験も欧米では始まって いる。 一方で，日本で本格的に取り組んできた共通自己抗原を標的としたペプチドワクチン療法は未だ承認された ものがなく, 開発に苦戦している。本稿では，まず近年有効性が示されたがん免疫療法やネオアンチゲンについて 概説し，後半は特に日本に扔けるがんに対する免疫療法の開発状況を期待とともに紹介する.

\section{1.はじめに}

がん免疫療法は，手術，抗がん剂，放射線治療に 続く第 4 の治療法として古くから期待されてきた が，これまではその期待に十分にこたえることが できなかった。 しかし, 近年, 抗 CTLA-4 抗体, 抗 PD-1 抗体, 抗 PD-L1 抗体などのいわゆる免疫チェッ クポイント阻害抗体の登場により，その劇的かつ 長く効く抗腫瘍効果は世界を驚かせ，さらには， CD19 を標的とした CAR-T 細胞療法は CD19 陽性造 血器腫瘍に対して極めて高い奏効率を示し, 今や,

国立研究開発法人国立がん研究センター 先端医療開発センター危疫療法開発分野
がんに対する免疫の存在，それらの治療法の有効性 について疑う者はいなくなった。一方で，ここ最近 日本で本格的に取り組んできたぺプチドワクチン療 法に代表されるがんワクチン療法はまだ承認された ものがなく, 開発に苦戦している。本稿では，がん に対する免疫療法全体の開発状況を期待とともに概 説する.

\section{2. 近年有効性が示されたがん免疫療法}

(1)リンパ球除去前処置後の腫瘍浸潤リンパ球

（Tumor infiltrating T lymphocytes: TIL）移入療法

Rosenberg SA らの, メラノーマの TIL を体外で大 量培養し，化学療法や免疫抑制剤の投与，X線全身 照射による体内のリンパ球除去後に，培養した TIL 
を移入する治療法が，70\%を超える奏効率を誇って きた ${ }^{1)}$.この治療によりすでに 1000 人以上の治癒 不能と言われた進行メラノーマの患者が完全治癒し ているというから驚きである，全身のリンパ球を除 去する意味は, 我々の体にはリンパ球の数を一定に 保つホメオスターシスが成立しているが，一旦リン パ球をゼロにしてスペースをつくり，そこに体外で 大量培養したがん細胞を殺せるリンパ球を戻してあ げると，ホメオスターシスにより，戻したリンパ球 が増殖して，体中ががんを殺すリンパ球だらけにな るというしくみ（Homeostatic proliferation）を使っ たものであるとともに，Treg などの抑制性リンパ 球を一過性に除去することで, 抗腫瘍免疫応答を増 強できるというものである，近年この治療法の効果 の根拠が, 後に述べるが, 遺伝子変異に由来する免 疫原性の高い非自己変異ペプチドであることが明ら かにされてきている（メラノーマは紫外線による遺 伝子変異が極めて多いがん種である)。比較的 TIL を増やすことが容易なメラノーマではこの治療は成 功しているが, 固形がんでも同様な治療が成り立つ かどうかは今後の課題である. 日本でも慶應大学で メラノーマと子宮頸がんを対象とした臨床試験がス タートした。

\section{(2)免疫チェックポイント阻害抗体療法}

免疫チェックポイント阻害剤の開発の成功は言 うまでもなく, 抗 CTLA-4 抗体, 抗 PD-1 抗体, 抗 PD-L1 抗体の開発にとどまらず，他の様々な $\mathrm{T}$ 細 胞の抑制シグナルを解除するもの，活性化シグナル を増強するものなど様々な治療薬が開発されてお り, それらと他の治療法との併用療法の臨床試験も 数えきれないほど実施されている。メラノーマや非 小細胞肺がん, 腎がんのみならず, 様々ながん種（頭 頝部がん, 膀胱がん, 胃がん, 食道がん, ホジキン リンパ腫, B 細胞系の悪性リンパ腫, 肝細胞がん, 小細胞肺がん等) に対して, 各種の抗 PD-1 抗体お よびそのリガンドである PD-L1 分子をブロックす る抗 PD-L1 抗体療法が有効性を示して期待されて いる反面，大腸がんや膵がんなどの治療成績は芳 しくない，大腸がんに拈いては，DNA マイクロサ テライト不安定性（microsatellite instability: MSI）が 高い大腸がんに限っては，PD-L1 が発現しており， 抗 PD-1 抗体が著効することが示されている，免疫 チェックポイント阻害療法ががんに著効する場合の 根拠としても，遺伝子変異が多いことが示されている.
一方で，いいことばかりではなく，免疫チェック ポイント阻害剤にともなう副作用（immune related Adverse Event (irAE) ) として, 胃腸障害, 肝障害, 肺臓炎, 皮虐障害（中毒性表皮壊死症を含む），神 経障害, 内分泌障害 (甲状腺機能低下, 副腎不全, 下垂体炎）等が生じることが知られており，著効を 示す患者が限られていること, 治療費が高額なこと, いつまで投与すればいいのか不明なことなどが問題 となっている.

\section{(3)遺伝子改変 $\mathbf{T}$ 細胞移入療法}

自己のリンパ球に特定の抗原に対する抗原受容体 遺伝子をウイルスベクターなどで導入・発現させ, 人工的にがん抗原特異的に改变した $\mathrm{T}$ 細胞を体外 増幅してから輸注する治療法の開発が注目を集めて いる. 主な方法として，がん抗原ペプチドを特異的 に認識する T 細胞受容体 (T-cell receptor, TCR) や, がん細胞表面に発現している標的抗原に対するキメ ラ抗原受容体 (chimeric antigen receptor, CAR) を遺 伝子導入する方法がある（図 1 ）.

TCR については，各種がん抗原（MART-1, gp100, p53, CEA, NY-ESO-1 等) に対する抗原受容体遺伝 子改変 $\mathrm{T}$ 細胞療法の早期臨床試験が行われ有効例 が確認されている ${ }^{2-6)}$ ，日本でも夕カラバイオ・三 重大学を中心としたグループが, MAGE-A4, NYESO-1の TCR を用いた医師主導治験を実施中であ る. CARについては, 細胞内活性化・シグナル伝 達部分を改良した第二世代以降の導入ベクターを用 い始めて以降, 特に既治療 CD19 陽性造血器腫瘍に おいて高い寛解率を示す事が相次いで報告されてい $る^{7-11)}$. 現在さらに, 他の抗原を標的とした早期臨 床開発も行われているが, 固形がんを対象とした臨 床試験においては，まだ画期的な成果は報告されて いないのが現状である，日本オリジナルの固形がん にも著効を示すような遺伝子導入 $\mathrm{T}$ 細胞療法の開 発が期待される。

これらの治療では, 強力な臨床効果の反面, 急激 な腫瘍細胞の傷害による腫瘍崩壊症候群も起こり得 る. 抗原受容体遺伝子改変 $\mathrm{T}$ 細胞療法では, 当初 の想定を越えた標的抗原または類似抗原の正常組織 での発現に対する反応性 (off-target effect)による死 亡例が報告されており，抗原（ペプチド）の特異性 の確保が求められる。また CAR 遺伝子導入 $\mathrm{T}$ 細胞 療法ではサイトカイン遊離症候群 (cytokine release syndrome, CRS）を引き起こす頻度が高いと報告さ 


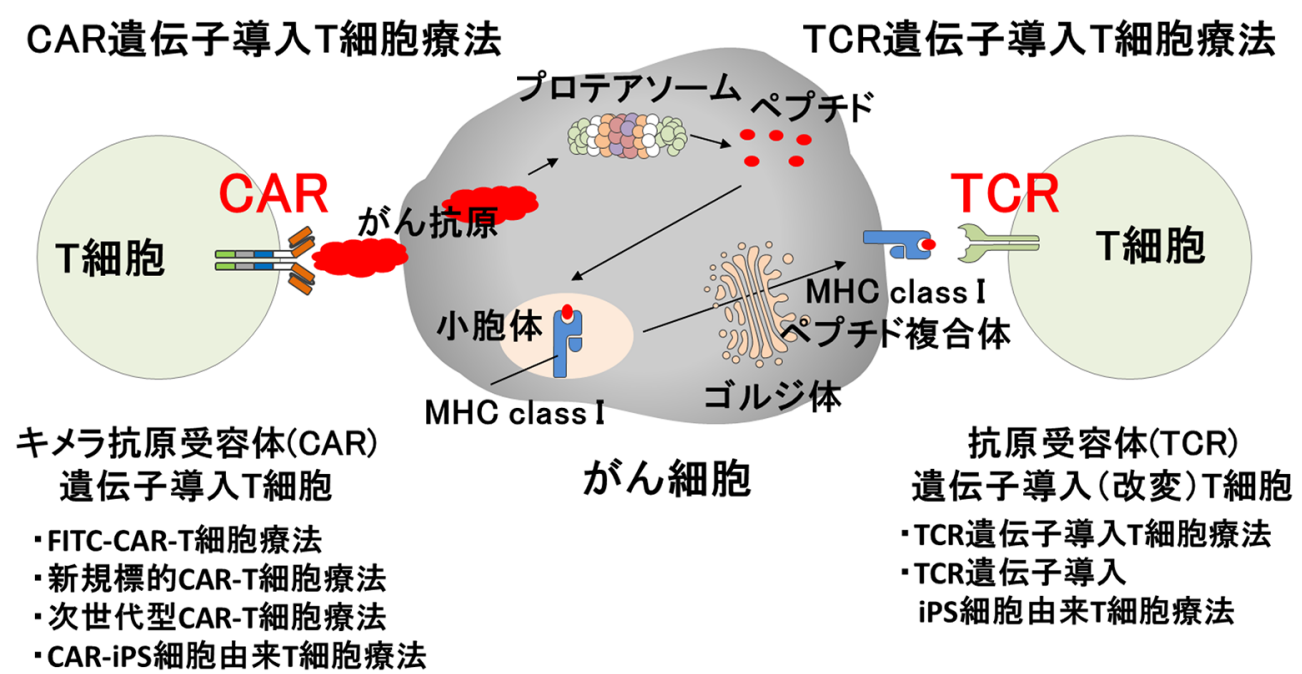

図 1 遺伝子導入 $\mathrm{T}$ 細胞療法の開発

日本オリジナルの固形がんにも効く遺伝子導入 $\mathrm{T}$ 細胞療法の開発を

れている.CRPが高值になると特に注意が必要で, ステロイド投与のタイミングを逸しないことが重要 である。重篤な場合は抗 IL-6レセプター抗体投与 が有効とされている.

\section{3. 腫瘍特異的変異抗原（ネオアンチゲン）}

腫瘍特異的変異抗原は, 今まさに Neoantigen 齐 オアンチゲンと呼ばれ大きく注目されている。メラ ノーマでは紫外線により多くの遺伝子変異が生じて おり，喫煙者の肺がんでも同様である，遺伝子変異 によりアミノ酸にも変異が生じるとそれが異物のペ プチドとして HLA に提示され，T細胞に認識され やすいことがわかっている，前述した TIL 移入療 法や免疫チェックポイント阻害療法ががんに著効す る場合の根拠として，この遺伝子変異が多いことが 示されている，実際，抗 PD-1 抗体が著効を示すが ん種には遺伝子変異が多いことが知られている. 次 世代シーケンサーやバイオインフォーマティックス の技術の発展も相まって，このような事実ととも に，遺伝子変異は患者個々によって極めて多様であ ることが明らかとなってきた。この技術を使って個 別化がんワクチン療法が可能ではないかと考えられ， いよいよ腫瘍特異的変異抗原（ネオアンチゲン）由 来がんワクチンを用いた個別化がんワクチン療法の 臨床試験が現実のものとなり，マウスモデル等での エビデンスに基づいて ${ }^{12-15)}$ ，欧米で様々な試験が始 まっている（図 2）。これまでの共通自己抗原を標 的としたがんワクチン療法の奏効率をはるかにしの ぐ成績が出るのか，期待を持って見守りたい，さら に, Rosenberg SA らは，ネオアンチゲンを認識する
細胞傷害性 $\mathrm{T}$ 細胞（CTL）の $\mathrm{T}$ 細胞受容体（TCR） を同定して，がんワクチンよりも抗腫瘍効果の高い $\mathrm{TCR}$ 遺伝子導入 $\mathrm{T}$ 細胞療法を個別化がん免疫療法 に応用しょうとしている（図 3 ）。

\section{4. がんペプチドワクチン療法の開発は 苦戦している}

1991 年の Boon らによるメラノーマ抗原 MAGE の同定 ${ }^{16)} に よ り ，$ CTL が，がん細胞表面の HLA に 提示されているぺプチドを認識してがん細胞を殺傷 していることに科学的なエビデンスが得られて以 来, 多数のがん抗原が同定され, 主にはがん細胞に 特異的に高発現し，なおかつ発現頻度の高い自己抗 原を用いたがんワクチンの臨床試験が行われてき た. Rosenberg SA が 2004 年に，がんワクチンの腫 瘍縮小効果を示す Objective response は $2.6 \%$ に過ぎ ないことを発表した ${ }^{17)}$ が，日本ではそれでも固形 がんに対するがん抗原由来のペプチドを同定し，臨 床試験を行うという試みが次々に行われ，様々な施 設から有効例の報告も相次いで，いくつかの成果は 企業治験に引き継がれている，がんペプチドワクチ ン療法は，患者の QOL を保ったまま生存期間を延 ばせる，あるいは再発を予防できる可能性のある 治療法として期待されたが，まだ承認されたもの はないのが現状である。そんな中，抗 CTLA-4 抗体 や抗 PD-1 抗体といった免疫抑制分子阻害抗体や, CD19-CAR 遺伝子導入 $\mathrm{T}$ 細胞療法が，高い腫瘍縮 小効果とともに華々しく登場し, 益々がんワクチン に失望の眼差しが降り注ぎつつある。現在実施中の 企業治験，あるいは今後の併用治療の成功により， 


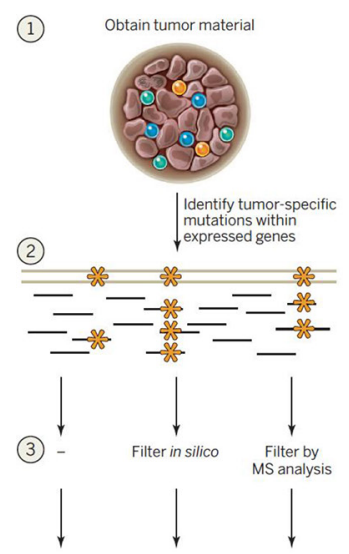

(4) Assess T cell recognition
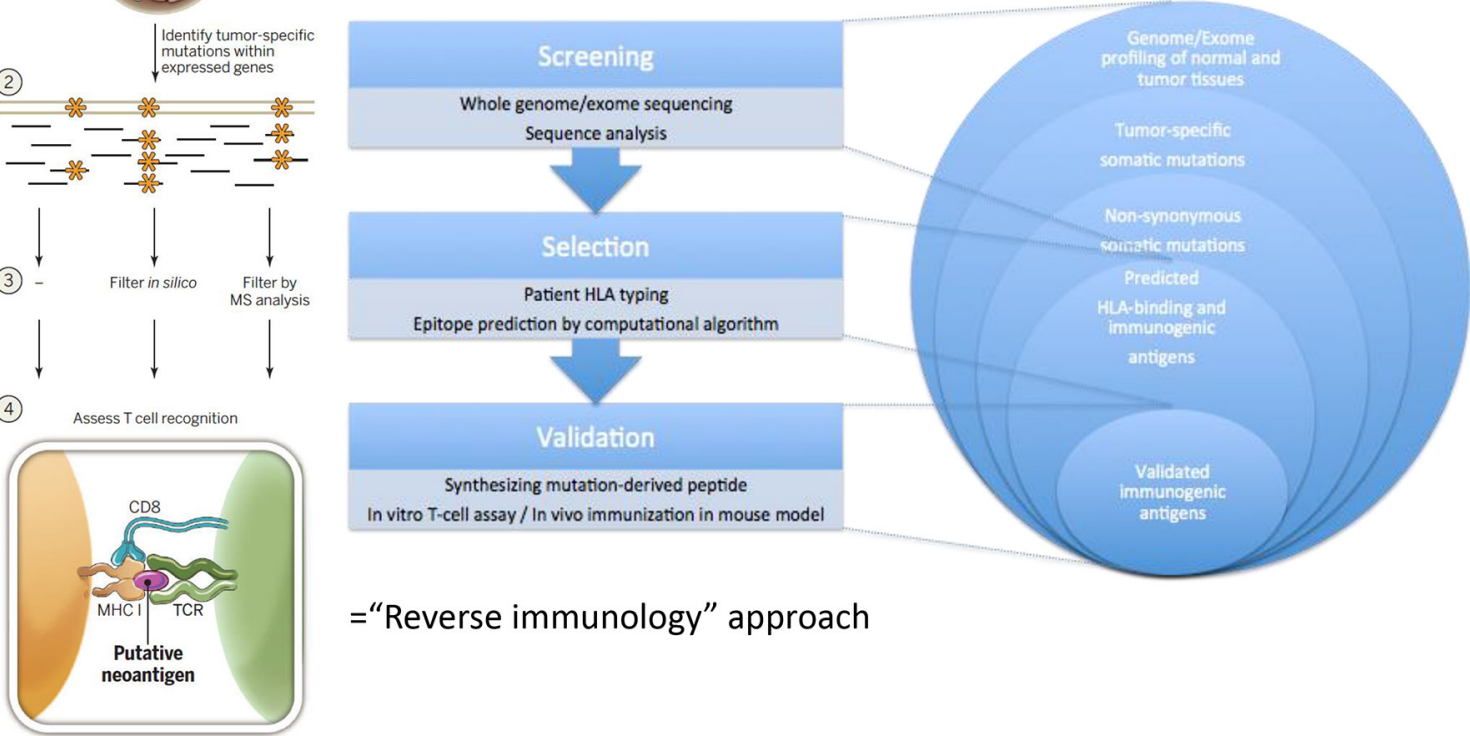

="Reverse immunology" approach

図 2 次世代シークエンサーとバイオインフォーマティックスの技術革新により，ネオアンチゲンを同定しての患者個別のがん ワクチン療法の臨床試験が可能な時代となった

欧米では既にいくつか臨床試験も始まっている. Ton N. Schumacher and Robert D. Schreiber. Science. 348: 69, 2015. より引用改変.

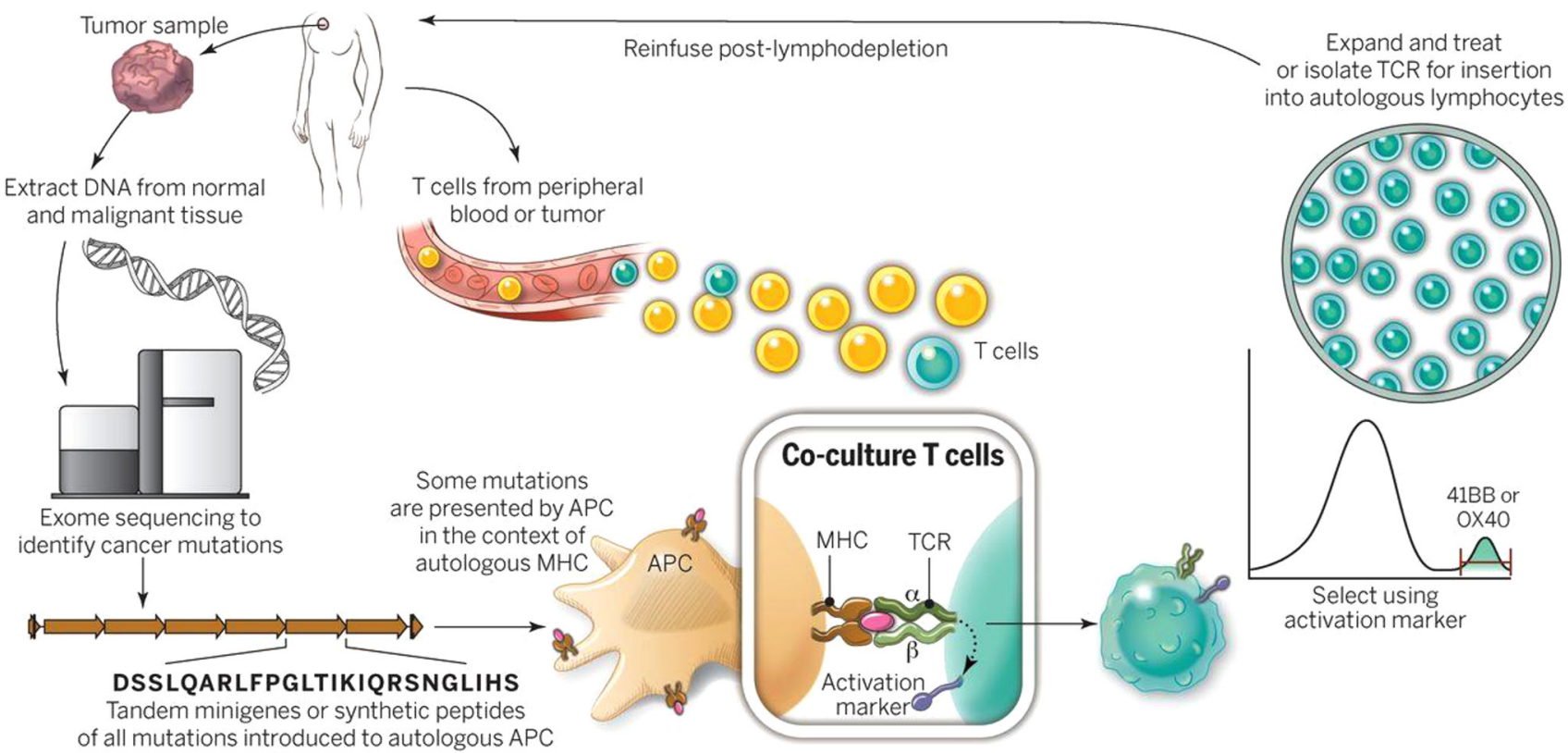

図 3 患者がん組織検体を使用し, 遺伝子変異由来抗原ペプチドとそれを認識する TCR を同定し治療へ応用することも可能 がんワクチンよりも抗腫瘍効果の高い TCR 遺伝子導入 $\mathrm{T}$ 細胞療法を個別化がん免疫療法に応用。 しかし, 個別化医療として の TCR 遺伝子導入 $\mathrm{T}$ 細胞自家移植治療の費用は極めて高額. Rosenberg SA, Restifo NP. Science. 348: 62-68, 2015. より引用.

ペプチドワクチンが医薬品として承認され，一発逆 転してほしいと願うばかりである。

著者らは glypican-3（GPC3）ががん特異的抗原 であることを見出し，特異的な CTLを誘導できる HLA-A2 拘束性 GPC3 ${ }_{144-152}$ (FVGEFFTDV), HLAA24 拘束性 GPC3 ${ }_{298-306}$ (EYILSLEEL) ペプチドを同
定し ${ }^{18)}$ ，肝細胞がんを中心として GPC3 ペプチドワ クチン療法の様々な臨床試験を実施してきた ${ }^{19-21)}$.

ワクチンの安全性と免疫学的有効性を確認し, 臨床 効果を誘導する可能性を示し, その成果は企業に導 出されたが，今後の開発に暗雲が垂れ込めている. 卵巣明細胞腺がんを対象とした臨床試験でも抗腫瘍 
効果が得られた症例を複数経験しており, 進行がん でも確かに効いたと言える症例は存在するが，現時 点では共通自己抗原を標的としたがんペプチドワク チン療法の腫瘍縮小効果は限定的であると言わざる を得ない.ペプチド特異的 CTL を多数誘導できる 優れたペプチドワクチンがあっても，そもそもがん 細胞表面の HLA class I 分子に十分なぺプチドが提 示されていないと, がん細胞の傷害は起こらない. 著者らはペプチド腫瘍内局注療法 ${ }^{22)}$ や，免疫調節 因子に関与する抗体とワクチンとの併用療法 ${ }^{23)}$ な ど, ペプチドワクチン療法の効果増強法の開発にも 取り組んできた。

それでは再発予防効果はどうか？ 著者らは, 肝細胞がん根治的治療後 40 例を対象として, GPC3 ペプチドワクチン療法を補助療法として 1 年 2 年 再発率を評価する単アームの臨床第 2 相試験を実 施した。GPC3 発現陰性は予後良好因子のため, GPC3 発現陽性例に限ってコントロール群と比較す ると, GPC3 ペプチドワクチン療法によって, 再発 率を抑えられる可能性が示唆された ${ }^{24)}$. しかし, 一 方で, 1 種類の共通自己抗原を標的としたペプチド ワクチンでは再発を完全に抑えることはできないこ とも明らかとなった，食道がんにおいては根治的治 療後の再発予防効果を検証するペプチドカクテルワ クチンの企業治験も実施されているが, 期待通りの 結果が出るか注目されている，個別化がんワクチン 療法の考え方も導入すれば, 切除後も再発率の高い がん種の再発予防法につながるかもしれないし, 肝 細胞がん発症予備群である肝炎・肝硬変患者の肝細 胞がん発症予防法こそ, がんワクチンでなんとかし たいものである。

一方, GPC3 ペプチドワクチン療法臨床試験の副 産物として, ワクチン投与患者の末梢血やがん組織 から, 多種類の GPC3 ペプチド特異的 CTLクロー ンの樹立に成功した。これらの一部は, GPC3 ペプ チドを提示しているがん細胞を殺傷する能力の高い ものであり ${ }^{25)}$ ，これらの TCR をクローニングする ことにより, TCR 遺伝子導入 $\mathrm{T}$ 細胞療法の開発に 応用可能である. 著者らは, 京都大学 iPS 細胞研究 所の金子らとともに, iPS バンクを用いて, GPC3 ペプチド特異的 TCR を遺伝子導入したiPS 細胞由 来の $\mathrm{T}$ 細胞を作製してがん治療に応用する共同研 究を既に開始している。これらの GPC3ペプチド 特異的 TCR は, 投与局所の発赤腫脹以外には特に ペプチドワクチン療法の有害事象を認めなかった
患者の体内の CTL からクローニングしたものであ り，すなわちその TCR は安全性が担保されている。 $\mathrm{TCR}$ 遺伝子導入 $\mathrm{T}$ 細胞療法は, ペプチドワクチン 療法に比較して一般に抗腫瘍効果に優れており, GPC3 ペプチドを提示する進行がんに対する治療法 として開発に期待している。

著者らは，GPC3 ペプチドワクチンに引き続き, 小児固形がんを対象としたペプチドカクテルワクチ ン療法の臨床第 1 相試験を医師主導治験として完了 し，同じく著者らが同定した HSP105 ペプチドワク チン療法 ${ }^{26)}$ の医師主導治験をスタートした。これ らの臨床試験がペプチドワクチン療法の開発につな がれば申し分ないが，仮に劇的な抗腫瘍効果を見い だせなかったとしても，TCR 遺伝子導入 T 細胞療 法の開発に望みをつなぐことができる.

\section{5. 著者らが関与している日本発のがん免疫療法の 開発について}

がん免疫療法の開発が大成功を抢さめた今, 日本 としては指をくわえて黙ってみているわけにはいか ない. 著者らは様々な有望なシーズを持つ研究者と 連携して国立がん研究センターでの臨床応用を目指 している。そのうちのいくつかを紹介する.

東京大学松島らは, 担がんマウスに抗 CD4 抗体 を投与して CD4 陽性細胞（免疫抑制性 Treg のみな らず，Th2, pDC, NKTなど）を除くと抗原特異的 CD8 陽性メモリーCTL の所属リンパ節での著明な, 抗原特異的, 抗原依存的増殖 - 活性化と CTL のが ん部位への浸潤が起こり, 強力な抗腫瘍効果が生じ ることを示し, さらには, 抗 CD4 抗体と様々な免 疫チェックポイント抗体（とりわけ抗 PD-1/PD-L1 抗体), 抗がん剂が相乗的/相加的に作用し劇的な 抗がん作用を示すことを示した ${ }^{27)}$. 松島らは現在, AMED の支援も受けながら IDAC Theranostics, Inc. とともに, 強力な $\mathrm{NK}$ 細胞依存性 ADCC 活性を有 するヒト型化脱フコシル化（ポテリジェント）抗 CD4 抗体の GMP 生産, GLP 基準での安全性試験を 進めており, 今年中に国立がん研究センターで first in human 医師主導第 1 相臨床治験を開始する予定で ある。

$\mathrm{CAR}$ 遺伝子導入 $\mathrm{T}$ 細胞療法は血液腫瘍において は華々しい成果を得ているものの, 固形がんにおい てはまだ有望な成績は得られていないのが現状であ る. 山口大学玉田らは, 固形がんにも通用する次世 代型の CAR-T 細胞療法の開発を目指している。 そ 
の一つは，がん認識抗体と，玉田らが開発したキメ ラ抗原受容体 (FITC-CAR) 遺伝子導入 $\mathrm{T}$ 細胞 ${ }^{28)}$ の 組み合わせによって，治療効果を保持しつつ制御を 可能にしたシステムである。このシステムの治療法 により，以下の 4 点により，従来の CAR-T 細胞療 法の欠点を克服できると期待している.

1. 標的分子に対する抗体との併用により，単一の コンストラクトで様々ながんを認識し, 攻撃で きる。

2. すでに臨床応用されている抗体において，治療 効果の増大，適応の拡大が見込まれる。

3. 複数の抗体を併用することにより, 発現量の低 い分子群も標的となり，その減少・矢失にも対 応できる。

4. CAR-T 細胞の機能は抗体依存性に制御される ため, 抗体投与の中止により CAR-T 細胞の機 能をシャットダウンすることが可能となる.

また，iPS 細胞テクノロジーを用いた免疫細胞療 法の開発ももはや夢ではない（図４）。熊本大学千 住らの，IFN $\beta$ あるいは $\gamma$ 産生 iPS 細胞由来ミエロ イド系免疫細胞ライン (iPS-ML) については，が ん腹膜播種マウスモデルでの有効性は示されてお $り^{29,30)}$ ，iPS 細胞テクノロジーを用いた免疫細胞療 法では，一番臨床応用に近いと考えられる。今後は 腹膜播種での臨床応用ではなく，肝転移を対象とし た臨床試験の計画に変更し, 医師主導治験の実施 を目指してさらに非臨床開発を進める。京都大学 金子との共同研究「glypican-3 を標的としたiPS 細 胞由来再生 $\mathrm{T}$ 細胞療法の開発」において, まずは glypican-3 ペプチド特異的 CTL クローンを iPS-T 細 胞化することに成功した。今後は TCR 遺伝子導入 $\mathrm{T}$ 細胞療法の開発， $\mathrm{CAR}$ 遺伝子導入 $\mathrm{T}$ 細胞療法の 開発も進めていく. iPS 細胞由来 $\mathrm{T}$ 細胞を活用する ことのメリットとしては， $\mathrm{T}$ 細胞の疲弊や老化の影 響が除かれていること，度重なる繰り返し治療や iPS 細胞段階での確実な遺伝子操作が可能であるこ となどがあげられるが, iPS バンクを使用することで, 普遍化や低コスト化につながり，独創性を保ちなが ら創薬としての可能性を高めることができる（図 5 ).

\section{6.おわりに}

抗 CTLA-4 抗体や抗 PD-1 抗体など免疫抑制分子 阻害抗体の奏効率は，ホジキンリンパ腫を除けば, 最大でも $30 \%$ （メラノーマの場合）であり，他の がんでは 10～20\%程度と推定されている。これら の治療法は高額であり，自己免疫の有害事象も生じ る.今後の課題は, どのような患者に有効なのか, 有効な場合，いつまで投与を続ければいいのかとい うバイオマーカーの探索であり，さらには免疫抑制 分子阻害療法で効果が認められない多くの患者に対 する治療法の開発である。遺伝子変異の多いがんで は，ネオアンチゲン由来の個別化ペプチド群のワク チン療法が救世主になるかもしれない.ペプチドワ クチンよりも明らかに抗腫瘍効果が高いと考えられ ている TCR 遺伝子導入 $\mathrm{T}$ 細胞療法を用いた個別化 ネオアンチゲン認識 TCR 遺伝子導入 $\mathrm{T}$ 細胞療法が 実現すれば，画期的な臨床効果も期待できる。一方， 遺伝子変異の少ないがんでは，免疫抑制機構を解除

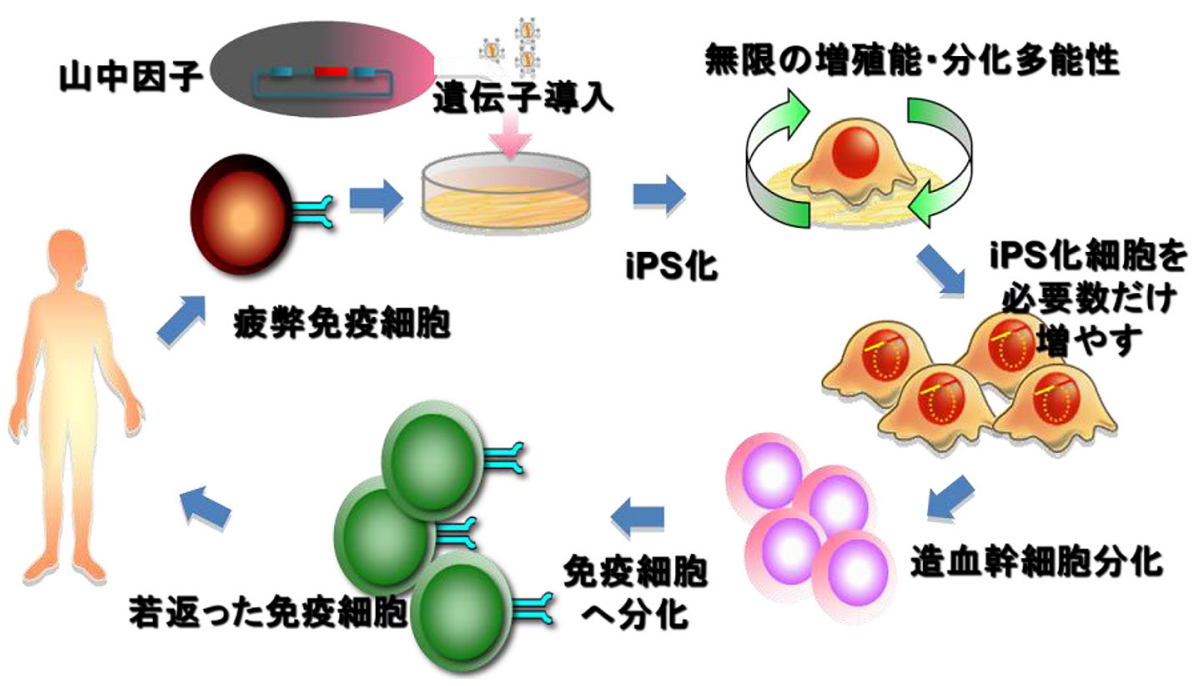

図 4 iPS 細胞由来免疫細胞療法の開発

日本の強みを活かした iPS 細胞のがん治療への応用, iPS 細胞由来免疫細胞の臨床応用を. 図は京都大学 iPS 細胞研究所金子 新研究室より提供. 


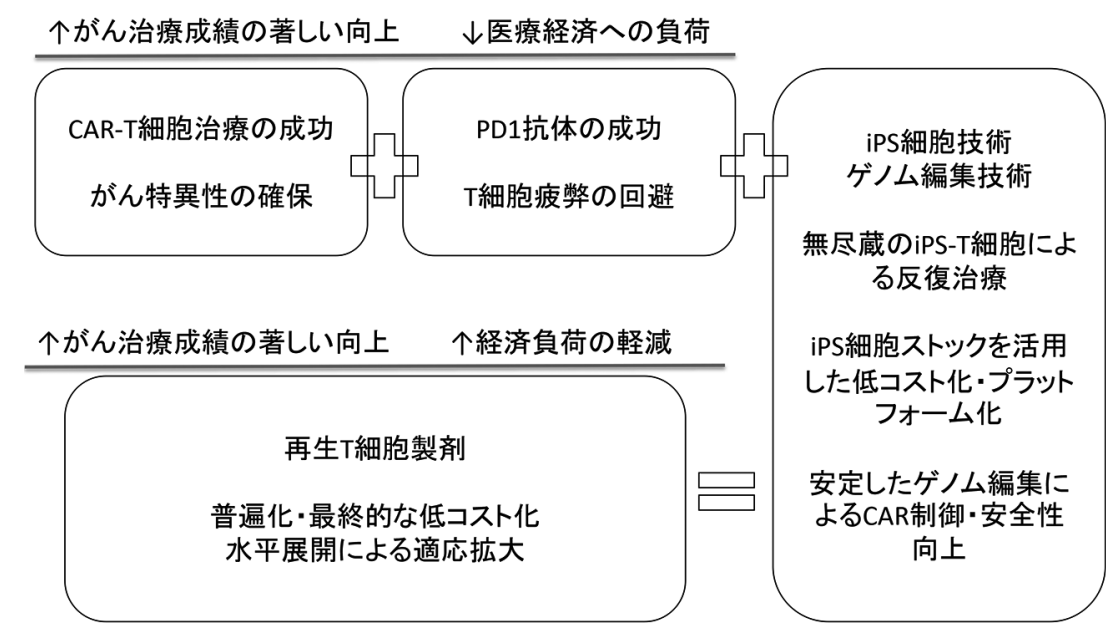

図 5 がん抗原に特異的な再生 $\mathbf{T}$ 細胞製剤の利点

創薬を目指す上で様々なメリットのある iPS 細胞由来 $\mathrm{T}$ 細胞を活用。

図は京都大学 iPS 細胞研究所 金子 新研究室より提供.

しても免疫応答を惹起することが困難であり，がん の排除を誘導できないことが明らかにされており， ネオアンチゲンを標的としたがん免疫療法だけでは まだ不十分と考えられる。そこでは，GPC3のよう な共通抗原あるいは患者個々のがんに固有の自己抗 原を標的としたがん免疫療法が活躍するかもしれな い.すべてのがん患者に有効ながん免疫療法の開発 を目指そうとするなら，個別化治療の開発に向うし かないのかもしれない、いずれにせよ, 本稿で述べ たようながん免疫療法，あるいは様々な治療法との 併用療法の開発が世界中で繰り広げられている。今 後, 一つでも多くの有効ながん免疫療法が登場して 承認され，多くの患者の元に届けられることに期待 したい.

\section{文献}

1) Rosenberg, S.A., Dudley, M.E.: Adoptive cell therapy for the treatment of patients with metastatic melanoma. Curr Opin Immunol. 21: 233-240, 2009.

2) Morgan, R.A., et al.: Cancer regression in patients after transfer of genetically engineered lymphocytes. Science. 314: 126-129, 2006.

3) Johnson, L.A., et al.: Gene therapy with human and mouse T-cell receptors mediates cancer regression and targets normal tissues expressing cognate antigen. Blood. 114: 535-546, 2009.

4) Parkhurst, M.R., et al.: T cells targeting carcinoembryonic antigen can mediate regression of metastatic colorectal cancer but induce severe transient colitis. Mol Ther. 19: 620-626, 2011.
5) Robbins, P.F., et al.: Tumor regression in patients with metastatic synovial cell sarcoma and melanoma using genetically engineered lymphocytes reactive with NY-ESO-1. J Clin Oncol. 29: 917924, 2011.

6) Linette, G.P., et al.: Cardiovascular toxicity and titin cross-reactivity of affinity-enhanced $\mathrm{T}$ cells in myeloma and melanoma. Blood. 122: 863-871, 2013.

7) Brentjens, R.J., et al.: Safety and persistence of adoptively transferred autologous CD19-targeted $\mathrm{T}$ cells in patients with relapsed or chemotherapy refractory B-cell leukemias. Blood. 118: 48174828, 2011.

8) Kochenderfer, J.N., et al.: B-cell depletion and remissions of malignancy along with cytokineassociated toxicity in a clinical trial of anti-CD19 chimeric-antigen-receptor-transduced $\mathrm{T}$ cells. Blood. 119: 2709-2720, 2012.

9) Brentjens, R.J., et al.: CD19-targeted T cells rapidly induce molecular remissions in adults with chemotherapy-refractory acute lymphoblastic leukemia. Sci Transl Med. 5: 177ra38, 2013.

10) Kochenderfer, J.N., et al.: Donor-derived CD19targeted $\mathrm{T}$ cells cause regression of malignancy persisting after allogeneic hematopoietic stem cell transplantation. Blood. 122: 4129-4139, 2013.

11) Davila, M.L., et al.: Efficacy and toxicity management of $19-28 \mathrm{z}$ CAR $\mathrm{T}$ cell therapy in B cell acute lymphoblastic leukemia. Sci Transl Med. 6: 224ra25, 2014.

12) van Rooij, N., et al.: Tumor exome analysis reveals neoantigen-specific T-cell reactivity in an 
ipilimumab-responsive melanoma. J Clin Oncol. 31: e439-442, 2013.

13) Snyder, A., et al.: Genetic basis for clinical response to CTLA-4 blockade in melanoma. $N$ Engl J Med. 371: 2189-2199, 2014.

14) Gubin, M.M., et al.: Checkpoint blockade cancer immunotherapy targets tumour-specific mutant antigens. Nature. 515: 577-581, 2014.

15) Rizvi, N.A., et al.: Cancer immunology. Mutational landscape determines sensitivity to PD-1 blockade in non-small cell lung cancer. Science. 348: 124128, 2015.

16) van der Bruggen, P., et al.: A gene encoding an antigen recognized by cytolytic $\mathrm{T}$ lymphocytes on a human melanoma. Science. 254: 1643-1647, 1991.

17) Rosenberg, S.A., et al.: Cancer immunotherapy: moving beyond current vaccines. Nat Med. 10: 909-915, 2004.

18) Komori, H., et al.: Identification of HLA-A2- or HLA-A24-restricted CTL epitopes possibly useful for glypican-3-specific immunotherapy of hepatocellular carcinoma. Clin Cancer Res. 12: 26892697, 2006.

19) Sawada, Y., et al.: Phase I trial of a glypican-3derived peptide vaccine for advanced hepatocellular carcinoma: immunologic evidence and potential for improving overall survival. Clin Cancer Res. 18: 3686-3696, 2012.

20) Sawada, Y., et al.: Remarkable tumor lysis in a hepatocellular carcinoma patient immediately following glypican-3-derived peptide vaccination: an autopsy case. Hum Vaccin Immunother. 9: 12281233, 2013.

21) Suzuki, S., et al.: Significant clinical response of progressive recurrent ovarian clear cell carcinoma to glypican-3-derived peptide vaccine therapy: two case reports. Hum Vaccin Immunother. 10: 338343, 2014.
22) Nobuoka, D., et al.: Intratumoral peptide injection enhances tumor cell antigenicity recognized by cytotoxic $\mathrm{T}$ lymphocytes: a potential option for improvement in antigen-specific cancer immunotherapy. Cancer Immunol Immunother. 62: 639652, 2013.

23) Sawada, Y., et al.: Programmed death-1 blockade enhances the antitumor effects of peptide vaccine-induced peptide-specific cytotoxic T lymphocytes. Int J Oncol. 46: 28-36, 2015.

24) Sawada, Y., et al.: Phase II study of the GPC3derived peptide vaccine as an adjuvant therapy for hepatocellular carcinoma patients. OncoImmunology. in press.

25) Yoshikawa, T., et al.: HLA-A2-restricted glypican3 peptide-specific CTL clones induced by peptide vaccine show high avidity and antigen-specific killing activity against tumor cells. Cancer Sci. 102: 918-925, 2011.

26) Sawada, Y., et al.: Identification of HLA-A2 or HLA-A24-restricted CTL epitopes for potential HSP105-targeted immunotherapy in colorectal cancer. Oncol Rep. 31: 1051-1058, 2014.

27) Ueha, S., et al.: Robust Antitumor Effects of Combined Anti-CD4-Depleting Antibody and Anti-PD-1/PD-L1 Immune Checkpoint Antibody Treatment in Mice. Cancer Immunol Res. 3: 631640, 2015.

28) Tamada, K., et al.: Redirecting gene-modified $\mathrm{T}$ cells toward various cancer types using tagged antibodies. Clin Cancer Res. 18: 6436-6445, 2012.

29) Koba, C., et al.: Therapeutic effect of human iPScell-derived myeloid cells expressing IFN- $\beta$ against peritoneally disseminated cancer in xenograft models. PLoS One. 8: e67567, 2013.

30) Senju, S., et al.: Application of iPS cell-derived macrophages to cancer therapy. Oncoimmunology. 3: e27927, 2014. 